Western University

Scholarship@Western

Obstetrics \& Gynaecology Publications

Obstetrics \& Gynaecology Department

9-1-2005

\title{
Roles of Na,K-ATPase in early development and trophectoderm differentiation.
}

Gerald M Kidder

Andrew J Watson

Follow this and additional works at: https://ir.lib.uwo.ca/obsgynpub

Part of the Obstetrics and Gynecology Commons

Citation of this paper:

Kidder, Gerald M and Watson, Andrew J, "Roles of Na,K-ATPase in early development and trophectoderm differentiation." (2005). Obstetrics \& Gynaecology Publications. 41.

https://ir.lib.uwo.ca/obsgynpub/41 


\title{
Roles of $\mathrm{Na}$,K-ATPase in Early Development and Trophectoderm Differentiation
}

\author{
Gerald M. Kidder and Andrew J. Watson
}

\begin{abstract}
Before implantation into the uterine wall, the mammalian embryo undergoes a period of cell division, cell shape change, and cell differentiation leading to the formation of an outer epithelium, the trophectoderm. The trophectoderm is the part of the embryo that initiates uterine contact and, after transformation to become the trophoblast, uterine invasion. Similar to the kidney nephron, the trophectoderm is a transporting epithelium with distinct apical and basolateral membrane domains; its function is to facilitate transepithelial $\mathrm{Na}^{+}$ and fluid transport for blastocoel formation. That transport is driven by $\mathrm{Na}$, Kadenosine triphosphatase (ATPase) localized in basolateral membranes of the trophectoderm. Preim. plantation embryos express multiple $\alpha$ and $\beta$ subunit isoforms of $\mathrm{Na}, \mathrm{K}$-ATPase, potentially constituting multiple isozymes, but the basolaterally located $\alpha^{1} \beta 1$ isozyme appears to function uniquely to drive fluid transport. Embryos unable to express $\alpha 1$ subunits because of targeted deletion of the gene are able to form a blastocoel, but they fail to maintain their integrity and expire during the peri-implantation period. Preimplantation embryos also express the $\gamma$ subunit, a modulator of $\mathrm{Na}, \mathrm{K}$-ATPase activity, but targeted deletion of that gene did not reveal an essential developmental role. The preimplantation embryo offers a unique model for understanding the roles of $\mathrm{Na}, \mathrm{K}$-ATPase subunit isoforms in epithelial development and transepithelial transport.
\end{abstract}

Semin Nephrol 25:352-355 (C 2005 Elsevier Inc. All rights reserved.

KEYWORDS preimplantation development, fluid transport, sodium pump, $\alpha$ subunit, $\beta$ subunit, $\gamma$ subunit

Tn addition to its well-studied roles in membrane potential $\mathrm{l}$ and membrane transport processes, $\mathrm{Na}, \mathrm{K}$-adenosine triphosphatase (ATPase) is thought to play an essential role in the earliest phase of mammalian ernbryogenesis, that which precedes implantation of the embryo into the uterus. Preimplantation development is a period of cell division, cell shape change, and cell differentiation leading to the formation of a polarized, transporting epithelium, the trophectoderm (reviewed by Watson and Barcroft ${ }^{1}$ ). The trophectoderm forms the outer wall of the blastocyst, the stage of development that immediately precedes implantation. It is the part of the conceptus that initiates uterine

From the Departments of Physiology and Pharmacology, Obstetrics and Gynaecology, and Paediatrics, University of Western Ontario, London, Ontario, Canada; and the Developmental Biology Program, Children's Healith Research Institute, London, Ontario, Canada.

Supported by grants from the Medical Research Council of Canada and the Canadian Institutes of Health Research.

Address reprint requests to Gerald M. Kidder, Department of Physiology and Pharmacology, University of Western Ontario, London, Ontario N6A $5 \mathrm{Cl}$, Canada. E-mail: gerald.kidder@md.uwo.ca contact and, after transformation to become the trophoblast, uterine invasion. Thus, trophectoderm development during preimplantation stages is a necessary antecedent to the events of implantation.

Although common to all eutherians, the processes involved in trophectoderm development have been studied most thoroughly in the mouse. After 3 cleavage divisions the mouse embryo undergoes a process of compaction in which blastomeres flatten against one another, polarize, and begin to assemble adherens, gap, and tight junctions (reviewed by Fleming et al ${ }^{2}$ ). Within the next 2 cell cycles the outer cells of the embryo become specialized as an epithelial monolayer. It is the ion- and fluid-transporting ability of this epithelial trophectoderm, driven by Na,K-ATPase, that enables blastocoel formation (cavitation). The blastocoelic fluid provides a unique extracellular environment for the inner cell mass, which eventually will give rise to the fetus. In addition to its roles in establishment of pregnancy, trophectoderm arises de novo from previously unspecialized blastomeres, making it a unique model for understanding how a polarized transporting epithelium develops. 3.4 


\section{Apical (extraembryonic fluid)}

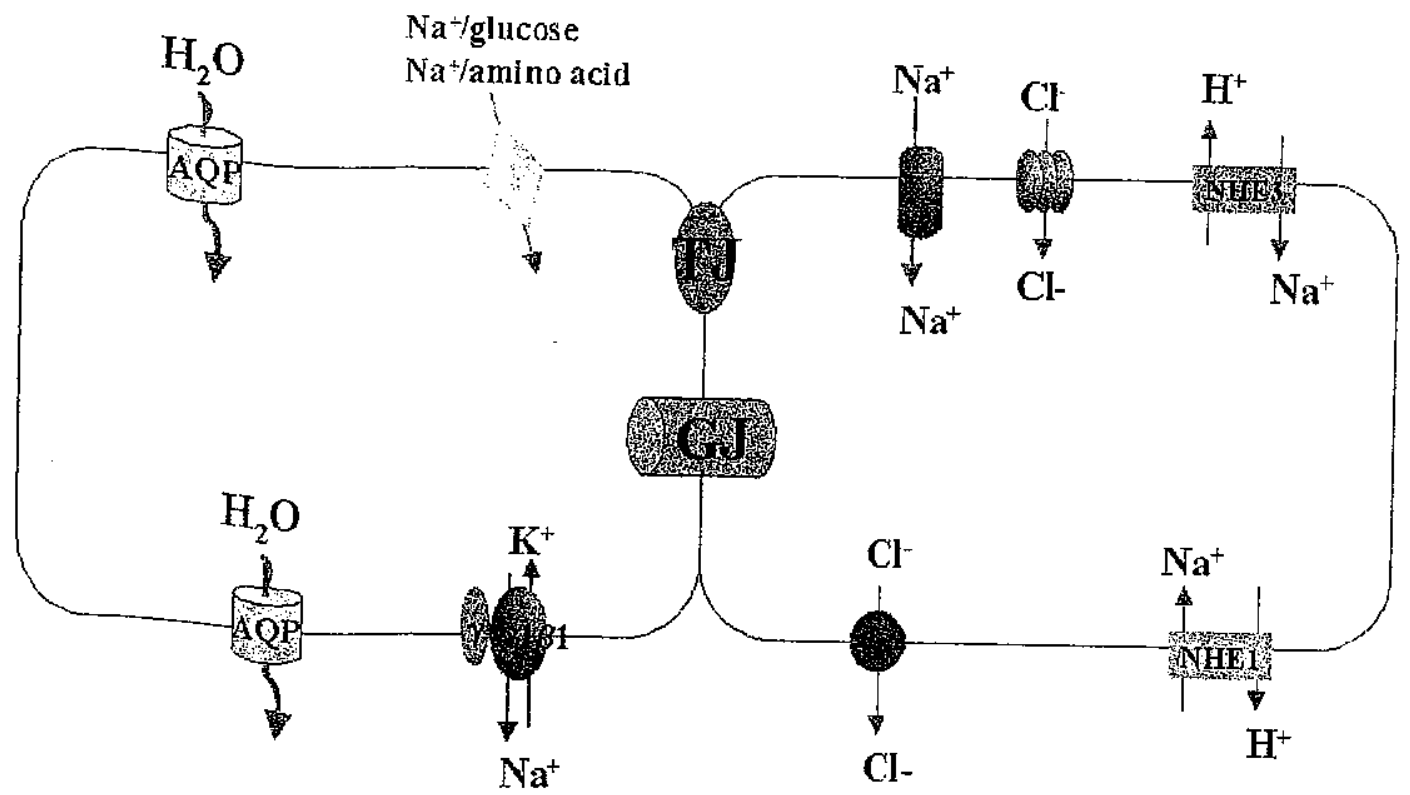

\section{Basolateral (blastocoelic fluid)}

Figure 1 Arrangement of transport systems known to be involved in transepithelial $\mathrm{Na}^{+}$transport in mouse trophectoderm. Two trophectoderm cells are shown, joined by a tight junction ( $\mathrm{gJ}$ ) and a gap junction (G). Basolateral sodium pumps ( $\mathrm{Na}, \mathrm{K}-\mathrm{ATP}$ ase) work in conjunction with apical routes of $\mathrm{Na}^{+}$entry that include the $\mathrm{NHE}-3$ isoform of the transporters. Wer (NHE), the arniloride-sensitive epithelial sodium channel, and $\mathrm{Na}^{+}$-linked glucose and amino acid Vectorial transport crosses the trophectoderm via aquaporin channels in both apical and basolateral membranes. to expand before impan $\mathrm{Na}^{+}$and water across the epithelial trophectoderm is hypothesized to cause the blastocoel cavity $\alpha 1$ and $\beta 1$ subunits antation. Although other $\mathrm{Na}$, K-ATPase subunit isoforms are present in trophectoderm cells, the subunits. Adapted from the only ones confined to basolateral membrane domains where they colocalize with $\gamma$

\section{The Role of the Sodium Pump in Blastocoel Formation}

$\mathrm{Na}, \mathrm{K}$-ATPase activity can be shown in all stages of preimplantation development, 5.6 but it seemingly plays a specific morphogenetic role at the time of cavitation. ${ }^{2}$ Expansion of the mammalian blastocoel is caused by transport of fluid across the trophectoderm, and this process can be prevented by ouabain, a specific inhibitor of Na,K-ATPase. ${ }^{7-10}$ The involvement of Na,K-ATPase also is supported by the fact that blastocoel expansion is retarded significantly in the absence of extraembryonic $\mathrm{Na}^{+}$or in the presence of inhibitors of $\mathrm{Na}^{+}$ channels or carriers with access to the apical trophectoderm surface. ${ }^{8}$ Clarification of the way the enzyme works in this context was provided by immunolocalization experiments showing that it is concentrated in the basolateral plasma membranes of the trophectoderm. ${ }^{11-13}$ Treatments that disrupt or prevent the development of the membrane-cytoskeletal complex in the blastocyst also prevent $\mathrm{Na}, \mathrm{K}-\mathrm{ATP}$ ase from assuming its basolateral localization, and fluid transport is blocked. ${ }^{34}$ The model on which these experiments were focused, shown in Fig. 1, is that the basolateral localization of
$\mathrm{Na}, \mathrm{K}$-ATPase allows polarized pumping of $\mathrm{Na}^{+}$across the trophectoderm, setting up an osmotic gradient to cause fluid to accumulate in the blastocoel. Several apical routes of $\mathrm{Na}^{+}$ entry into trophectoderm cells have been identified that would work in conjunction with basolateral sodium pumps to provide a transtrophectodermal $\mathrm{Na}^{+}$flux. ${ }^{8,14,15}$ Furthermore, several aquaporin family members have been identified in apical and basolateral trophectoderm membranes and evidence was presented that these aqueous channels facilitate the rapid movement of water into the blastocoel under neariso-osmotic conditions. ${ }^{16,17}$

\section{Sodium Pump $\alpha$ and $\beta$ Subunit Isoforms in Preimplantation Embryos}

Based on the co-expression of multiple $\alpha$ and $\beta$ subunit isoforms in preimplantation embryos of both mouse and cow, multiple (perhaps as many as 6) Na,K-ATPase isozymes could be present, adding complexity to our understanding of the roles that this enzyme plays in trophectoderm develop- 
Table 1 Expression of Na,K-ATPase Subunit Isoforms in Mouse Blastocysts

\begin{tabular}{lcccccccc}
\multicolumn{1}{c}{ Method } & $\alpha \mathbf{1}$ & $\alpha \mathbf{2}$ & $\alpha \mathbf{3}$ & $\alpha \mathbf{4}$ & $\beta \mathbf{1}$ & $\beta \mathbf{2}$ & \\
\hline RT-PCR & + & - & + & - & + & + & + \\
Western blot & + & - & + & ND & + & + & + \\
Immunofluorescence & Basolateral & & Cytoplasmic & ND & Basolateral & Cytoplasmic & Cytoplasmic \\
\hline
\end{tabular}

RT-PCR, reverse-transcription polymerase chain reaction; ND, not determined.

Data from MacPhee et al.13

ment and function (see Table 1). ${ }^{10,13}$ However, confocal immunofluorescence microscopy has revealed only $\alpha$ l and $\beta 1$ subunits in basolateral trophectoderm membranes, indicating that the $\alpha 1 \beta I$ isozyme is involved uniquely in active transport of $\mathrm{Na}^{+}$and water into the blastocoel. ${ }^{13,18}$ Interestingly, in the cow (but not the mouse), $\alpha 3$ subunits are present predominantly in apical membranes of the trophectoderm ${ }^{18}$; whether this subunit isoform has a specific role to play in the maximally expanding cow blastocyst remains to be determined. In both species, blastocoel formation is correlated temporally with up-regulation of expression of $\beta 1$ subunits, suggesting that it may be triggered by that event. $9,10,13,19$

In the mouse, specific functions for individual sodium pump subunit isoforms have been explored by targeted disruption of the encoding genes. For example, an essential role for $\alpha 2$ and $\beta 2$ subunits in preimplantation development has been ruled out by showing that mice lacking either of these subunits are born alive at full term. ${ }^{20,21}$ Absence of the $\alpha 1$ subunit, on the other hand, developmentally is lethal. ${ }^{21}$ Heterozygous mice that express only $\mathrm{I}$ copy of the $\mathrm{Na}, \mathrm{K}-\mathrm{ATP}$ ase $\alpha 1$ subunit gene are fertile and generally are healthy, but homozygous null offspring were not found among their progeny. Based on earlier studies (cited earlier), it was hypothesized that an active $\alpha l \beta l$ isozyme would be required to mediate blastocoel formation and that the absence of $\alpha$ l null mutant offspring therefore must reflect failure of the mutant embryos to reach the blastocyst stage and achieve competence to implant. Surprisingly, when development of the mutant embryos was followed-up in vitro, it was found that they can develop to the blastocyst stage in normal numbers and are indistinguishable morphologically from their wild-type counterparts. ${ }^{22}$ Eventually, however, the mutant blastocysts dissociated, losing trophectodermal integrity, and failed to escape from the zona pellucida, the extracellular matrix that surrounds the developing embryo. Because escape from the zona in vitro is known to result from the activity of a proteolytic enzyme secreted by the trophectoderm, ${ }^{23}$ this observation indicates that the health of the trophectoderm had been compromised in the absence of $\alpha 1$ subunits. The $\alpha 1$ null mutant blastocysts also were incapable of forming outgrowths in vitro, a process that mimics some aspects of implantation. ${ }^{22}$ These observations indicate that although the survival of $\alpha \mathrm{l}$ null mutant embryos is short-lived, they are able to progress to the blastocyst stage but die shortly after, during peri-implantation development. It remains to be determined whether expression of any of the other $\alpha$ subunit isoforms is altered in $\alpha 1$ null mutant embryos to maintain sodium pump activity, allowing the biastocoel to form.

\section{The $\gamma$ Subunit}

The $\gamma$ subunit is a small type I membrane protein, a member of the FXYD family, that modulates the activity of the sodium pump in specific cell types. ${ }^{24-26}$ It is most abundant in the kidney, where it is highly expressed in certain distal nephron segments. ${ }^{27-30}$ Despite the fact that the $\gamma$ subunit, unlike the $\alpha$ and $\beta$ subunits, is encoded by a single gene (designated FXYD2 by Sweadner and Rael ${ }^{26}$ ), there are $2 \gamma$ subunit isoforms in kidney with different $\mathrm{N}$-terminal amino acid sequences, most likely arising from alternate splicing. $26,31,32$ With the cloning of the mouse Fxyd2 gene it became apparent that there actually are 3 variants in that species, also differing in their $\mathrm{N}$-termini. ${ }^{33}$ Each of the $3 \mathrm{~N}$-termini links with the common transmembrane domain.

Given the functional similarities between the blastocyst trophectoderm and the kidney nephron, it was of interest to explore the possibility that $\gamma$ subunits also play a role in preimplantation development. The $\gamma$ subunit gene is transcribed continuously in the mouse preimplantation embryo from the 8-cell stage onward and $\gamma$ subunits accumulate and localize to the peripheries of blastomeres as development proceeds. ${ }^{34}$ While colocalizing with the $\alpha 1 \beta 1$ isozyme in the basolateral membranes of the trophectoderm, $\gamma$ subunits also appear to be expressed in the apical membranes where $\alpha$ and $\beta$ subunits are not detectable by immunofluorescence (Fig. 1).13,34,35 Messenger RNAs encoding both $\gamma a$ and $\gamma b$ variants are present in blastocysis. ${ }^{33}$ Mice were generated that lacked the common transmembrane-encoding sequence of the Fxyd2 gene, a deletion that would be expected to abolish the function of all $3 \gamma$ isoforms. Surprisingly, mice homozygous for this deletion were viable and fertile and without obvious pathology (Jones et al, ${ }^{36}$ ). The absence of any effect on blastocoel formation was confirmed by showing no correlation between the timing of blastocyst development and embryo genotype resulting from heterozygote crosses. The possibility that null mutant embryos were being rescued by $\gamma$ subunits contributed by the oocyte was ruled out by the fact that expected Mendelian ratios of offspring were obtained even from Fxyd2 $2^{-1-}$ dams. Thus, $\gamma$ subunits lack an essential role in preimplantation development.

\section{Summary}

Despite the expression of multiple members of each of the $\mathrm{Na}$,K-ATPase subunit gene families during preimplantation development, and determination of the role of the enzyme in supporting blastocoel formation by studies using pharmaco- 
logic inhibitors, we still have not defined the individual role of each expressed isoform. Thus far, the $\alpha \mathrm{l}$ isoform is the only one determined to play an essential role in preimplantation development. Research directed at understanding the role of $\mathrm{Na}, \mathrm{K}-\mathrm{ATPase}$ isozymes during embryogenesis will continue well into the future.

\section{Acknowledgments}

The authors would like to acknowledge the contributions of a talented group of trainees and technicians who have contributed greatly to this research from our laboratories including Lisa Barcroft, Kevin Barr, Dean Betts, Ashley Garrill, Holly Jones, Daniel MacPhee, and Cindy Pape.

\section{References}

1. Watson AJ, Barcroft LC: Regulation of blastocyst formation. Front Biosci $6: d 708-d 730,2001$

2. Fleming TP, Wilkins A, Mears A, et al: The making of an embryo: Short-term goals and long-term implications. Reprod Fertil Dev 16: 325-337, 2004

3. Watson AJ, Damsky $\mathrm{CH}$, Kidder GM: Differenciation of an epithelium: Factors affecting the polarized distribution of $\mathrm{Na}, \mathrm{K}$-ATPase in mouse trophectoderm. Dev Biol 141:104-114, 1990

4. Wiley LM, Kidder GM, Watson AJ: Cell polarity and development of the first epithelium. Bioessays 12:67-73, 1990

5. Van Winkle LJ, Campione AL: Ouabain-sensitive $\mathrm{Rb}^{+}$uptake in mouse eggs and preimplantation conceptuses. Dev Biol 146:158-166, 1991

6. Baltz JM, Smith SS, Biggers JD, et al: Intracellular ion concentrations and their maintenance by $\mathrm{Na}^{+} / \mathrm{K}^{+}$-ATPase in preimplantation mouse embryos. Zygote 5:1-9, 1997

7. DiZio SM, Tasca RJ: Sodium-dependent amino acid transport in preimplantation mouse embryos. III. $\mathrm{Na}^{+}-\mathrm{K}^{+}$-ATPase-linked mechanism in blastocysts. Dev Biol 59:198-205, 1977

8. Manejwala FM, Cragoe EJ Jr, Schultz RM: Blastocoel expansion in the preimplantation mouse embryo: Role of extracellular sodium and chloride and possible apical routes of their entry. Dev Biol 133:210-220, 1989

9. MacPhee DJ, Barr KJ, Watson AJ, et al: Role of the $\alpha$ and $\beta$ subunits of $\mathrm{Na}, \mathrm{K}-\mathrm{ATP}$ ase in trophectoderm differentiation and cavitation. Irophoblast Res 11:87-99, 1997

10. Betts DH, MacPhee DJ, Kidder GM, et al: Ouabain sensitivity and expression of $\mathrm{Na} / \mathrm{K}$-ATPase $\alpha$ - and $\beta$-subunit isoform genes during bovine early development. Mol Reprod Dev 46:114-126, 1997

11. Watson AJ, Kidder GM: Immunofluorescence assessment of the timing of appearance and cellular distribution of $\mathrm{Na} / \mathrm{K}-\mathrm{ATP}$ ase during mouse embryogenesis. Dev Biol 126:80-90, 1988

12. Kidder GM, Watson AJ: Gene expression required for blastocoel formation in the mouse, in Heyner S, Wiley L (eds): Early Embryo Development and Paracrine Relationships (UCLA Symposia on Molecular and Cellular Biology, New Series, Vol. 117). New York, Alan R. Liss, Inc., 1990, pp 97-117

13. MacPhee DJ, Jones DH, Barr KJ, et al: Differential involvement of $\mathrm{Na}, \mathrm{K}$ ATPase isozymes in preimplantation development of the mouse. Dev Biol 222:486-498, 2000

14. Wiley LM, Lever JE, Pape $\mathrm{C}$, et al: Antibodies to a renal $\mathrm{Na}^{+}$/ glucose cotransport system localize to the apical plasma membrane domain of polar mouse embryo blastomeres. Dev Biol 143:149-161, 1991

15. Barr KJ. Garrill A, Jones DH, et al: Contributions of $\mathrm{Na}^{+} / \mathrm{H}^{+}$exchanger isoforms to preimplantation development of the mouse. Mol Reprod Dev 50:146-153, 1998

16. Offenberg H, Barcroft LC, Caveney A, et al: mRNAs encoding aquapor- ins are present during murine preimplantation development. Mol Reprod Dev 57:1-8, 2000

17. Barcroft LC, Offenberg $\mathrm{H}$, Watson AJ: Aquaporin proteins in murine trophectoderm mediate transepithelial water movements during cavitation. Dey Biol 256:342-354, 2003

18. Betts DH, Barcroft LC, Watson AJ: Na/K-ATPase-mediated ${ }^{86} \mathrm{Rb}^{+}$uptake and asymmetrical trophectoderm localization of $\alpha \mathrm{l}$ and $\alpha 3 \mathrm{Na} / \mathrm{K}$ ATPase isoforms during bovine preattachment development. Dev Biol 197:77-92, 1998

19. Watson AJ, Pape C, Emanuel JR, et al: Expression of Na,K-ATPase $\alpha$ and $\beta$ subunit genes during preimplantation development of the mouse. Dev Genet 11:41-48, 1990

20. Magyar JP, Bartsch U, Wang Z-Q, et al: Degeneration of neural cells in the central nervous system of mice deficient in the gene for the adhesion molecule on glia, the 32 suburit of murine $\mathrm{Na}, \mathrm{K}$-ATPase. J Cell Biol 127:835-845, 1994

21. James PF, Grupp IL, Grupp $G$, et al: Identification of a specific role for the $\mathrm{Na}, \mathrm{K}$-ATPase $\alpha 2$ isoform as a regulator of calcium in the heart. Mol Cell 3:555-563, 1999

22. Barcroft $L C$, Moseley AE, Lingrel JB, et al: Deletion of the $\mathrm{Na} / \mathrm{K}-\mathrm{ATP}$ ase $\alpha 1$-subunit gene (Atplal) does not prevent cavitation of the preimplantation mouse embryo. Mech Dev 121:417-426, 2004

23. O'Sullivan CM, Rancourt SL, Liu SY, et al: A novel murine tryptase involved in blastocyst hatching and outgrowth. Reproduction 122:6171,2001

24. Béguin $P$, Wang $X$, Firsov D, et al: The $\gamma$ subunit is a specific component of the $\mathrm{Na}, \mathrm{K}-\mathrm{ATP}$ ase and modulates its transport function. EMBO J 16:4250-4260, 1997

25. Arystarkhova E, Wetzel RK, Asinovski NK, et al: The $\gamma$ subunit modulates $\mathrm{Na}^{+}$and $\mathrm{K}^{+}$affinity of the renal Na,K-ATPase. J Biol Chem 274:33183-33185, 1999

26. Sweadner KJ, Rael E: The FXYD gene family of small ion transport regulators or channels: cDNA sequence, protein signalure sequence, and expression. Genomics 68:41-56, 2000

27. Therien AG. Blostein R: Mechanisms of sodium pump regulation. Am J Physiol 279:C541-C566, 2000

28. Pu $\mathrm{HX}$, Cluzeaud $F$, Goldshlegger $\mathrm{R}$, et al: Functional role and immunocytochemical localization of the $\gamma_{a}$ and $\gamma_{b}$ forms of the $\mathrm{Na}_{1} \mathrm{~K}$-ATPase $\gamma$ subunit. J Biol Chem 276:20370-20378, 2001

29. Wetzel $\mathrm{RK}$, Sweadner KJ: Immunocytochemical localization of the $\mathrm{Na}$,K-ATPase $\alpha$ and $\gamma$ subunits in the rat kidney. Arn J Physiol 281: F531-F545, 2001

30. Arystarkhova E, Wetzel RK, Sweadner KJ: Distribution and oligomeric association of splice forms of the $\mathrm{Na}$, K-ATPase regulatory $\gamma$ subunit in rat kidney. Am J Physiol 282:F393-F407, 2002

31. Küster B, Shainskaya A, Pu HX, et al: A new variant of the $\gamma$ subunit of renal Na,K-ATPase. Identification by mass spectrometry, antibody binding, and expression in cultured cells. J Biol Chem 275:1844118446,2000

32. Sweadner kJ, Wetzel RK, Arystarkhova E: Genornic organization of the human FXYD2 gene encoding the $\gamma$ subunit of the Na,K-ATPase. Biochem Biophys Res Commun 279:196-201, 2000

33. Jones $\mathrm{DH}$, Golding $\mathrm{MC}$, Barr $\mathrm{KJ}$, et al: The mouse Na,K-ATPase $\gamma$ subunit gene (Fxyd2) encodes three developmentally regulated transcripts. Physiol Genomics 6:129-135, 2001

34. Jones DH, Davies TC, Kidder GM: Embryonic expression of the putative $\gamma$ subunit of the sodium pump is required for acquisition of fluid transport capacity during mouse blastocyst development. J Cell Biol 139:1545-155, 1997

35. Barcroft LC, Gill S, Watson AJ: Expression and co-localization of the gamma subunit of the Na/K-ATPase during bovine pre-attachment development. Reproduction 124:387-397, 2002

36. Jones DH, Li TY, Arystarkhova E, et al: Na, K-ATPase from mice lacking the $\gamma$ subunit (FXYD2) exhibitis altered $\mathrm{Na}^{+}$affinity and decreased thermal stability. J Biol Chem 280:19003-190ì, 2005 